\title{
Health promoting hospitals in Iran: Persian translation, cultural adaptation, content and face validation of self- assessment form of the standards of health promoting hospitals affiliated to the World Health Organization
}

\author{
Akbar Nikpajouh $^{1}$, Mohamad Amin Shahrbaf $^{2}$, Mahdyie Doayie $^{3}$, Maryam Mohseny ${ }^{4}$, Ali Ebadi ${ }^{5}$, Mahasti Alizadeh ${ }^{6}$, \\ Ali Hossein Zeinalzadeh ${ }^{5}$, Nastaran Laal ${ }^{3}$, Tolou Hasandokht ${ }^{7}$, Termeh Tarjoman ${ }^{8}$, Mina Ahmadi ${ }^{9}$, Leila Sabzmakan ${ }^{10}$, \\ Zahra Yekta ${ }^{11}$, Zahra Sanaei ${ }^{12}$, Mohamad Ali Seif-Rabiei*12
}

Received: 2 Aug 2017

Published: 3 Dec 2018

\begin{abstract}
Background: According to the World Health Organization, hospitals should assess their internal wards to improve health promotion services using self-assessment tools. To achieve this goal, standards of health promoting hospitals have been developed by the World Health Organization, and measurable elements and indicators have been defined to facilitate the practical application of these standards in planning, implementation, and evaluation of health promotion in hospitals. Moreover, a form has been developed for this self-assessment. Considering linguistic and cultural differences in various countries, standards must be written in equivalent texts and, then, their content and face validity should be examined.

Performing this process in a systemic and scientific way can guarantee that the same tools have been used, and thus the results obtained from different hospitals are comparable.

Methods: After the preparation phase (considering research aim, obtaining permission from the original designers, and determining the time), the following activities were done: translating the form from its original language to the target language, combining and compiling initial translations to a single translation, reversing the final version of the translation from the target language to the original language, obtaining cognitive information, revising and concluding, and determining the content and face validity of the translated form and final report.

After filling in the form, face validity was calculated using impact score formula. Content validity was measured using content validity ratio (CVR) and content validity index (CVI).

Results: After calculating the impact score, all 40 items showed a high impact score greater than 1.5 , representing the fact that all items are important. The minimum value of CVR for each of the 40 items was estimated to be 0.64 ; CVI of all items was greater than 0.79 .

Conclusion: Given the input of the standards of health promoting hospitals affiliated to the World Health Organization in National Accreditation of Iranian hospitals, the form was translated and found to be valid according to content and face validity and is available in Persian to be used in Iranian hospitals (Appendix 1).
\end{abstract}

Keywords: Health promotion, Hospital, Self-assessment

Conflicts of Interest: None declared

Funding: Research Council of Rajaie Cardiovascular, Medical, and Research Center

*This work has been published under CC BY-NC-SA 1.0 license.

Copyright $\odot$ Iran University of Medical Sciences

Cite this article as: Nikpajouh A, Shahrbaf MA Doayie M, Mohseny M, Ebadi A, Alizadeh M, Zeinalzadeh AH, Laal N, Hasandokht T, Tarjoman T, Ahmadi M, Sabzmakan L, Yekta Z, Sanaei Z, Seif-Rabiei MA. Health promoting hospitals in Iran: Persian translation, cultural adaptation, content and face validation of self-assessment form of the standards of health promoting hospitals affiliated to the World Health Organization. Med $J$ Islam Repub Iran. 2018 (3 Dec);32:120. https://doi.org/10.14196/mjiri.32.120

\section{Introduction}

In the Ottawa Charter, the concept of "health promotion" is defined as follows:

Corresponding author:Dr Mohamad Ali Seif-Rabiei, seifrabie@umsha.ac.ir

1. Rajaei Cardiovascular Medical and Research Center, Iran University of Medical Sciences, Tehran, Iran

2. Shahid Beheshti University of Medical Science, Tehran, Iran

3. Community Medicine Specialist, Iran University of Medical Sciences, Tehran, Iran

4. Department of Community Medicine, Faculty of Medicine, Shahid Beheshti University of Medical Sciences, Tehran, Iran

5. Vice Chancellor for Treatment, Tabriz University of Medical Sciences, Tabriz, Iran

6. Department of Family and Community Medicine, Faculty of Medicine, Tabriz University of Medical School, Tabriz Universi-

ty of Medical Sciences, Tabriz, Iran

7. Department of Community Medicine, Faculty of Medicine, Guilan University of Medical Sciences, Rasht, Iran

8. Department of Community Medicine, Faculty of Medicine, Tehran Medical Branch, Islamic Azad University, Tehran, Iran

9. Community Medicine Specialist, Shahid Beheshti University of Medical Sciences, Tehran, Iran

10. Department of Health Education \& Promotion, Alborz University of Medical Sciences, Karaj, Iran

11. Department of Community and Preventive Medicine, Urmia University of Medical Sciences, Urmia, Iran

12. Department of Community Medicine, School of Medicine, Hamadan University of Medical Sciences, Hamadan, Iran $\uparrow$ What is "already known" in this topic:

Hospitals use health promoting standards (HPH), developed by WHO, to assess their services and promote them.

\section{$\rightarrow$ What this article adds:}

The translated form of HPH standards is valid for self-assessment of hospitals and is available in Persian to be used in Iranian hospitals. 
Health promotion is the process of enabling people to increase their control over their health (1). An individual or a group should have the ability to identify and realize aspirations, satisfy needs, and change, and interact with the environment to achieve full physical, mental, and social health. Therefore, health is considered as a source of daily living and not as a goal of living. Health is a positive concept that emphasizes social and personal resources as well as physical capacities (2).

The Ottawa Charter has identified 5 key action areas for health promotion: (1) creating healthy society policy, (2) creating healthy supportive environments, (3) strengthening community action for health, (4) developing personal skills, and (5) retraining health services (3).

Considering the importance of health promotion policy in hospitals, it should be considered that hospitals are unique workplaces where a large number of employees are at risk of physical and psychological contacts during their clinical tasks. As many exposures in hospitals are unavoidable, it is imperative to follow the health promotion policy in hospitals (2).

Another reason for the importance of health promotion in hospitals is the fact that lifestyle factors are extremely important in the treatment and prognosis of diseases (3).

Hospitals play a central role in the health care system and are centers where modern medicine is practiced and research and education are performed. Therefore, they can affect the professional behavior of other organizations and social groups. In some countries, up to $20 \%$ of the public are admitted to hospitals annually and many people refer to hospitals as visitors (4).

Considering some changes in public expectations and an increasing number of chronic patients needing continuous support and also considering the staff who are exposed to physical and emotional strains, it is required that hospitals move towards health promotion as a key service for patients and staff (2).

Recommendations of Vienna on health promoting hospitals are divided into 3 general categories: (1) basic principles of health promotion in hospitals, (2) strategies for implementing health promotion in hospitals, (3) participating in the network of health promoting hospitals (5).

The World Health Organization movement of health promoting hospitals has focused on 4 areas: (1) health promotion of patients, (2) health promotion of staff, (3) changing the organization to a place for health promotion, and (4) participation in health promotion of the society. These 4 areas are reflected in the definition of a health promoting hospital: "A health promoting hospital creates an organized and cultural structure, in addition to comprehensive and high-quality medical and nursing services, to promote health and introduce itself as a physical environment promoting health and actively cooperating with its community." (2).

The dominant approach used to manage the quality of hospitals is to set standards for services. Health promotion is the main topic in preserving quality of life. However, reviewing the existing quality standards of health care to create a reference for health promotion activities leads to a few results. In hospitals, health promotion standards are essential for ensuring the quality of services offered in this field (3).

Standards for health promoting hospitals are the results of a series of workshops and consultations, which were piloted in 36 hospitals in 9 European countries and were found to be relevant and usable. Based on the feedback from the pilot project, substandards and measurable elements were identified and the steps were planned to develop further and facilitate the standards. Each standard contains standard composition, description of purpose, and definition of substandard. The standards are related to patients and define responsibilities and activities related to health promotion as part of the services offered to patients in the hospital. These standards are mainly generic with the focus on patients, staff, and management. Specific standards are based on evidence and are considered in accordance with patients' specific needs. The quality goals described in the standards refer to professional, organizational, and patient-related quality issues. In the 2004 edition, 68 substandards were used as the self-assessment tool for pilot implementation (6).

To facilitate the practical use of these standards in planning, implementation, and evaluation of health promotion in hospitals, measurable elements and indicators were defined, and a tool was designed for their self-assessment.

The latest version of the standards and substandards of health promoting hospitals has a total of 40 substandards that can be used for all hospitals that wish to perform selfassessment of the standards of health promoting hospitals $(4,7)$.

The aim of the World Health Organization is not to externally assess the hospitals that are the members of European health promoting hospitals network; however, hospitals should internally assess themselves using selfassessment tools to improve health promotion services. These standards are considered in the public sector and quality agencies, and accreditation bodies have placed the standards in a set of existing standards for health promotion in hospitals (8).

The final 5 standards of health promoting hospitals affiliated to the World Health Organization refer to following issues: (1) management policy, (2) patient assessment, (3) information and patient interventions, (4) promotion of healthy workplace, and (5) continuity and cooperation. These standards are associated with the process of disease and define the health promotion-related responsibilities and activities as an integral part of the services offered to patients in the hospital. Each standard contains standard composition, objectives, and definition of the substandards (6).

These standards were placed under review and it was confirmed that they are understandable, meaningful, relevant, and applicable. International quality standards organizations were encouraged to integrate these standards with their existing standards and use them in the future (4).

This study aimed to translate and culturally adjust the self-assessment form of the standards of health promoting hospitals affiliated to the WHO in Persian. 


\section{Methods}

This study contained 2 separate parts as follow:

a. Developing the Persian version of the self-assessment form of the standards of health promoting hospitals affiliated to World Health Organization, which consists of 5 steps:

1. Translating the form to Persian

2. Analyzing the Persian translations

3. Reversing the translation in English

4. Informing the expert committee to exchange views with other experts

5. Assessing face validity

b. Determining the validity of the Persian version:

1. Face validity

2. Content validity

Self-assessment forms of the standards of health promoting hospitals affiliated to WHO were translated from English to Persian by 2 experts. In the next step, 2 translated texts were compared qualitatively and, in some cases, 2 translators and 1 native English speaker were consulted to finally select the most appropriate translations for phrases, integration, and combination of primary translations, and a single translation of the form was obtained. Then, 2 other translators, who had not seen the original English texts, were asked to reverse the final translated version to English. The aim was to ensure the accuracy of the translation. Then, after comparing the version backtranslated to English with the original version and consulting with the 2 translators and also 1 native English speaker, conceptual sameness (ie, the conceptual content of the original form) and overall quality of translations were investigated.

In the next step, to determine face validity, 2 experts who were proficient in English and specialized terms were asked to examine the desirability of phrases used in the Persian form for clarity (using simple and understandable terms); then, small changes were made to simplify the form and make it more understandable (9).

Validity is the efficiency of the test to measure the attribute that the test is designed for (10).

Impact score was used to determine face validity. Moreover, 5-point Likert scale was considered for each of the 40 items: it is quite important (5 score), it is important (4 score), it is relatively important (3 score), it is slightly important ( 2 score), and it is not important (1 score).

To determine validity, the form was given to 10 managers responsible for improving the quality of hospitals and the faculty members of the Department of Social Medicine who were active in prevention and health promotion clinics of the training hospitals. After the forms were filled out, face validity was calculated using impact score formula.

Impact score $=$ Frequency $(\%)$ x Importance

To ensure face validity for each item, their impact score should not be less than 1.5 , and only the questions with the impact score of greater than 1.5 are acceptable.

To determine difficulty in understanding the phrases and words and the proper relationship between the items, 10 quality managers of hospitals were interviewed and minor changes were applied to the form based on their comments.

Content validity usually answers the following questions: Does the designed tool include all the main aspects of the measured concepts? Do the structures of the tool measure what they should examine? Are the parts and the universality of the tool acceptable in the view of relevant specialists $(11,12)$ ?

Content validity test is performed in 2 ways:

Content validity ratio (CVR) was designed by Lawshe. To calculate this indicator, the point views of experts on the contents of the test are used and the aim of the test is explained to them. Then, the operating definitions related to the contents of questions are presented to them and they are asked to classify each question according to a 3-point Likert scale: "the item is necessary", "the item is useful but not necessary", and "the item is unnecessary". Then, content validity is evaluated with a simple formula.

Based on the number of experts who examined the questions, minimum acceptable value of CVR is determined according to the following table. Those questions with CVR less than acceptable value should be excluded because they do not have acceptable content validity (Table 1).

Content validity index (CVI): The methods developed by Waltz and Basel are used to evaluate the content validity index (13). Experts evaluate the relevance, clarity, and simplicity of each item based on a 4-point Likert scale. They evaluate the relevance of each item with one of the options of "not relevant", "relatively relevant", "relevant" and "quite relevant". They evaluate the simplicity of each item with one of the followings: "not simple", "relatively simple", "simple", and "quite simple". They evaluate the clarity of each item with one of the options of "not clear", "relatively clear", "clear", and "quite clear".

Minimum acceptable value of CVI is equal to 0.79 and, if it is less than 0.79, that item should be excluded (14).

Therefore, CVR was used to ensure that the most important and accurate content was selected; CVI was used to ensure that the items of the tool were designed in the best way to measure the designed content.

To determine validity, the form was examined by 10 experts. They were asked to comment on each of the 40 items of the tool by selecting one of the following options: "the item is necessary", "the item is useful but not necessary", and "the item is unnecessary". The answers were evaluated by CVR formula.

After calculating CVR, the experts were asked again to comment on each of the 40 items in terms of 3 criteria of "relevant", "simplicity", and "clarity", according to a 4point Likert scale. Then, CVI was calculated. 
Given calculated CVI, CVR, and impact score, the research team did not eliminate any items and those items that were determined as inappropriate items ( 7 items) were revised, and those of them that needed to be corrected were corrected, and the experts were asked to evaluate them again.

\section{Results}

Standard 1 requires hospitals to have a written policy for health promotion, which should be a part of the overall organization quality system with the aim of improving health outcomes. The policy is aimed for patients, families, and staff. Questions 1 to 9 of the form are related to standard 1 (Appendix 1).

Standard 2 describes that hospitals should ensure that patients' needs are assessed to promote health, prevent disease, and rehabilitate. Questions 10 to 16 of the form are related to standard 2 (Appendix 1).

Standard 3 indicates that hospitals should provide the necessary information about the most important factors affecting the illness or health for patients and that health promotion interventions should be considered in all patients. Questions 17 to 22 of the form are related to standard 3 (Appendix 1).

Standard 4 grants authority to hospital administrators to
Table 1. Minimum Values of CVR

\begin{tabular}{cc}
\hline No. of Panelists & Min. Value \\
\hline 5 & .99 \\
6 & .99 \\
7 & .99 \\
8 & .75 \\
9 & .78 \\
10 & .62 \\
11 & .59 \\
12 & .56 \\
13 & .54 \\
14 & .51 \\
15 & .49 \\
20 & .42 \\
25 & .37 \\
30 & .33 \\
35 & .31 \\
40 & .29 \\
One Tailed Test, p=.05 & \\
When all say "essential," the CVR is computed to be 1.00, (It is adjusted to .99 \\
for ease of manipulation). \\
When the number saying "essential" is more than half, but less than all, the \\
CVR is somewhere between zero and .99.
\end{tabular}

stabilize the conditions to develop the hospital as a healthy workplace. Questions 23 to 32 of the form are related to standard 4 (Appendix 1).

Standard 5 is related to cooperating with other health service sectors and institutions (2). Questions 33 to 40 of the form are related to standard 5 (Appendix 1).

\begin{tabular}{|c|c|c|c|c|}
\hline Standard & Question & CVR & CVI & Impact Score \\
\hline Standard 1: & 1 & 0.99 & 0.83 & 4.2 \\
\hline \multirow[t]{8}{*}{ Management Policy } & 2 & 0.82 & 0.90 & 4.2 \\
\hline & 3 & 0.64 & 0.90 & 4.5 \\
\hline & 4 & 0.82 & 0.80 & 4.3 \\
\hline & 5 & 0.82 & 0.83 & 4.6 \\
\hline & 6 & 0.64 & 0.87 & 4.4 \\
\hline & 7 & 0.64 & 0.80 & 3.6 \\
\hline & 8 & 0.82 & 0.80 & 4.1 \\
\hline & 9 & 0.82 & 0.83 & 4.4 \\
\hline Standard 2: & 10 & 0.82 & 0.90 & 4.3 \\
\hline \multirow[t]{6}{*}{ Patient Assessment } & 11 & 0.64 & 0.87 & 3.9 \\
\hline & 12 & 0.82 & 0.90 & 4.3 \\
\hline & 13 & 0.82 & 0.80 & 3.6 \\
\hline & 14 & 0.64 & 0.83 & 4.3 \\
\hline & 15 & 0.82 & 0.90 & 3.8 \\
\hline & 16 & 0.82 & 0.87 & 4.2 \\
\hline Standard 3: & 17 & 0.64 & 0.87 & 4.6 \\
\hline \multirow[t]{5}{*}{ Patient Information and Intervention } & 18 & 0.64 & 0.80 & 4.0 \\
\hline & 19 & 0.82 & 0.90 & 4.7 \\
\hline & 20 & 0.82 & 1.00 & 4.8 \\
\hline & 21 & 0.82 & 1.00 & 4.7 \\
\hline & 22 & 0.64 & 0.93 & 4.5 \\
\hline Standard 4: & 23 & 0.99 & 0.90 & 4.5 \\
\hline \multirow[t]{9}{*}{ Promoting a Healthy Workplace } & 24 & 0.64 & 0.80 & 4.3 \\
\hline & 25 & 0.64 & 1.00 & 4.5 \\
\hline & 26 & 0.82 & 0.93 & 4.2 \\
\hline & 27 & 0.82 & 1.00 & 4.6 \\
\hline & 28 & 0.64 & 1.00 & 4.3 \\
\hline & 29 & 0.64 & 0.90 & 3.9 \\
\hline & 30 & 0.64 & 0.87 & 4.1 \\
\hline & 31 & 0.64 & 0.83 & 4.5 \\
\hline & 32 & 0.82 & 0.80 & 4.2 \\
\hline Standard 5: & 33 & 0.82 & 0.83 & 3.9 \\
\hline \multirow{7}{*}{ Continuity and Cooperation } & 34 & 0.64 & 0.80 & 3.8 \\
\hline & 35 & 0.82 & 0.80 & 4.3 \\
\hline & 36 & 0.64 & 0.83 & 4.0 \\
\hline & 37 & 0.82 & 0.87 & 4.0 \\
\hline & 38 & 0.82 & 0.83 & 4.1 \\
\hline & 39 & 0.82 & 0.90 & 4.6 \\
\hline & 40 & 0.64 & 0.80 & 3.7 \\
\hline
\end{tabular}


After calculating the impact score, it was found that all the items have an impact score greater than 1.5, meaning that all items are important in terms of target group (Table 2).

With respect to CVR, given that the number of experts is 10 , the score of each item should be greater than 0.62 according to Lawshe's table (Table 1). Minimum value of each item was estimated to be 0.64 (Table 2).

The results showed that CVI of 33 items were greater than 0.79 , and 7 of them had a CVI between 0.7 and 0.79 , and none of them had a CVI less than 0.7 . Thus, the items were revised, CVI was calculated again, and the values of CVI of all 40 items were greater than 0.79 after revision.

\section{Discussion}

This study was conducted to provide the Persian translation of the self-assessment tool for the standards of health promoting hospitals.

There are several studies for HPH standards as a management tool for hospitals in Europe and Asia (15-17). However, we translated these standards to Persian and implanted them for assessing health promoting hospitals in Iran.

The need for setting standards for health promotion in hospitals in the network of health promoting hospitals in Europe was felt and was developed in a 2-year period (19). This process followed the principles of ALPHA (Agenda for Leadership in Programs for Health care Accreditation), set up by ISQUA (International Society for Quality in Health Care), to make the standards more practical and acceptable for all hospitals and to integrate these standards with quality standards existing in hospitals (2, 19).

A significant increase in countries' willingness to implement accreditation programs is observed and International Society for Quality in Health Care (ISQUA) is placed in the center of this process. For many years, ISQUA has held many conferences and meetings in the field of accreditation. At the conference held in 1998, this society developed a program called ALPHA, which contains 3 powerful levers:

1. To internationally prove that accreditation is a valid evaluation process;

2. To prove that external evaluation using accreditation procedures is a way to measure the activities of national organizations with a single meaning on the run;

3 . To be responsive to the international needs of accreditation and be able to share knowledge and experiences in the field of accreditation (12).

Therefore, since the principles of the ALPHA program have been met in the standards of health promoting hospitals, these standards can also be used in planning the national accreditation of hospitals, including in Iran.

In the management and leadership heading of the standards of accreditation of Iran hospitals in 2010, the following phrase was mentioned to encourage hospitals to meet the standards of health promoting hospitals: "To ensure the implementation of the planned actions towards prevention and health promotion in 4 areas of service recipients, employees, hospital environment, and society by collabo- rating with senior officials of the society" (19).

In the management and leadership part of the third edition of the national accreditation standards for hospitals in Iran in 2016, it was indicated that "Hospitals will act for prevention and health promotion." and the following 2 measures were considered:

Measure 1: Participating in prevention and health promotion within the patient domain;

Measure 2: Participating in prevention and health promotion within the staff domain (20).

Health promoting hospitals should consider health promotion standards in 4 domains: patients, staffs, hospital environment, and interacting with the community. In 2 domains of patients and staffs, the last edition of accreditation of hospitals in Iran has been considered for all hospitals. Two domains of hospital environment and interacting with community are considered for superlative hospitals $(2,21)$.

After calculating the impact score, it was found that all the 40 items had an impact score greater than 1.5, meaning that all items are important in terms of target group. The lowest impact score was 3.6 and related to item 7 [There are facilities and structures required for health promotion, including resources, space, and equipment, in our hospital.]. The highest impact score was 4.8 and related to item 20 [Educational information related to public health is available in our hospital, including printed information (pamphlets, brochures, magazines) and online resources (websites, etc.)].

About CVR, given that the number of experts is 10 , the score of each item should be greater than 0.62 , according to Lawshe's table (13). Minimum value of each item was estimated to be 0.64 .

The results indicated that CVI of 33 items was greater than 0.79 , and 7 of them had a CVI between 0.7 and 0.79 , and none of them had a CVI less than 0.7. Thus, the items were revised, CVI was calculated again, and the values of CVI of all 40 items were greater than 0.79 after revision.

The present study was performed to provide translation, cultural adaptation, and evaluation of content and face validity of self-assessment form of the standards of health promoting hospitals affiliated to World Health Organization in Persian to provide a reliable form for Iranian hospitals. This form is reliable according to face and content validity and is now available in Persian for Iranian hospitals (Appendix 1).

\section{Limitations}

This study had several limitations. First, the translation, cultural adaptation as well as content and face validity of the form were conducted in university hospitals of large cities, and thus small towns or non-academic hospitals may have difficulty using it.

Second, the form was evaluated and its content and face validity was examined by the managers responsible for improving the quality of hospitals and the faculty members of the Department of Social Medicine who were active in prevention and health promotion clinics of these training hospitals. However, experts from small hospitals in small towns were not involved. 
According to the correspondence we had with Dr. Oliver Groene, the first author of these standards, we hope to put the next edition of the form at the disposal of hospitals in Iran after publishing this work in English and overcoming these limitations.

\section{Conclusion}

Considering the presence of nearly 1000 hospitals around the country and the need for a policy covering patients and staff domains in all hospitals, the availability of authentic translation of the standards of health promoting hospitals is of utmost importance.

This study was conducted to help Iranian hospitals achieve a reliable form. Based on the face and content validity, the form is consistent with the English version and is available to Iranian hospitals in Persian and is attached to this article.

Hospitals in Iran can use this tool, with 40 substandards available in 5 main standards of health promoting hospitals, to self-assess their hospital and examine their progress in observing these standards over time.

\section{Financial and ethical issues}

This was the result of the approved research article, with the ethical code of RHC.AC.IR.REC.1396.21, in a meeting dated 2017.10.6, with a research code of 9619 of the Research Council of Rajaie Cardiovascular, Medical, and Research Center.

\section{Conflict of Interests}

The authors declare that they have no competing interests.
11. Yaghmaei F. Content validity and its estimation. J Med Educ. 2003; 3(1): 25-27.

12. Rutherford-Hemming T. Determining content validity and reporting a content validity index for simulation scenarios. Nurs Educ Perspect. 2015;36(6):389-93.

13. Lawshe $\mathrm{CH}$. A quantitative approach to content validity. Person Psychol. 1975;28(4):563-75.

14. Zamanzadeh V, Ghahramanian A, Rassouli M, Abbaszadeh A, Alavi-Majd H, Nikanfar A-R. Design and implementation content validity study: development of an instrument for measuring patientcentered communication. J Caring Sci. 2015;4(2):165.

15. Groene O, Jorgensen S, Fugleholm A, Møller L, Garcia-Barbero M. Standards for health promotion in hospitals: development and pilot test in nine European countries. Int J Health Care Qual Assur. 2005;18(4):300-7.

16. Groene O, Alonso J, Klazinga N. Development and validation of the WHO self-assessment tool for health promotion in hospitals: results of a study in 38 hospitals in eight countries. Health Promot. Int. 2010;25(2):221-9.

17. Lee CB, Chen MS, Chu CMY. The health promoting hospital movement in Taiwan: recent development and gaps in workplace. Int J Publc Health. 2013;58(2):313-7.

18. Pelikan JM, Gröne O, Svane JK. The International HPH Networka short history of two decades of development. Clin Health Promt. 2011;1(1):32-6.

19. World Health Organization. Quality and accreditation in health care services: a global review. Geneva: World Health Organization. 2003.

20. Yousefinezhad T, Mosadeghrad AM, Arab M, RamezaniI M, Akbari Sari A. An Analysis of Hospital Accreditation Policy in Iran. Iran J Public Health. 2017;46(10):1347-1358.

21. Bahadori M, Ravangard R, Alimohammadzadeh KH. The Accreditation of Hospitals in Iran. Iran J Public Health. 2015 Feb; 44(2):295-296.

\section{References}

1. World Health Organization. The Ottawa charter for health promotion: first international conference on health promotion, Ottawa, 21 November 1986. Geneva: WHO. 1986.

2. Brandt E, Schmidt W, Dziewas R, Groene O. Implementing the Health Promoting Hospitals strategy through a combined application of the EFQM excellence model and the balanced scorecard. In: Groene O, Garcia-Barbero M (eds) Health promotion in hospitals: evidence and quality management. World Health Organization Regional Office for Europe. Copenhagen- Denmark. 2005.

3. Nikpajouh A. Persian Translation of Health Promotion in Hospitals: evidence and quality management. Tehran 2010.

4. Groene O. Implementing health promotion in hospitals: Manual and self-assessment forms. WHO Regional office for Europe. Copenhagen- Denmark. 2006.

5. World Health Organization. The Vienna recommendations on health promoting hospitals. WHO Regional office for Europe. CopenhagenDenmark. 1997.

6. Groene O, Jorgensen SJ, Garcia-Barbero M. Standards for health promotion in hospitals: self-assessment tool for pilot implementation. WHO European Office for Integrated Health Care Services Division of Country Support. Barcelona. 2004.

7. Nikpajouh A. Standards of health promoting hospitals: 68 or 40 measurable elements? Health Promot Perspect. 2017;7(3):109.

8. Nikpajouh A. persian translation of Implementing health promotion in hospitals Manual and Self assessment forms. 1st ed. O G, editor. Tehran: Iranian Moaser; 2010.

9. Rahman A, Iqbal Z, Waheed W, Hussain N. Translation and cultural adaptation of health questionnaires. J Pakistan Med Assoc. 2003;53(4):142-7.

10. Sullivan GM. A Primer on the Validity of Assessment Instruments. J Grad Med Educ.2011;3(2):119-120. 
A. Nikpajouh, et al.

\section{Appendix 1}

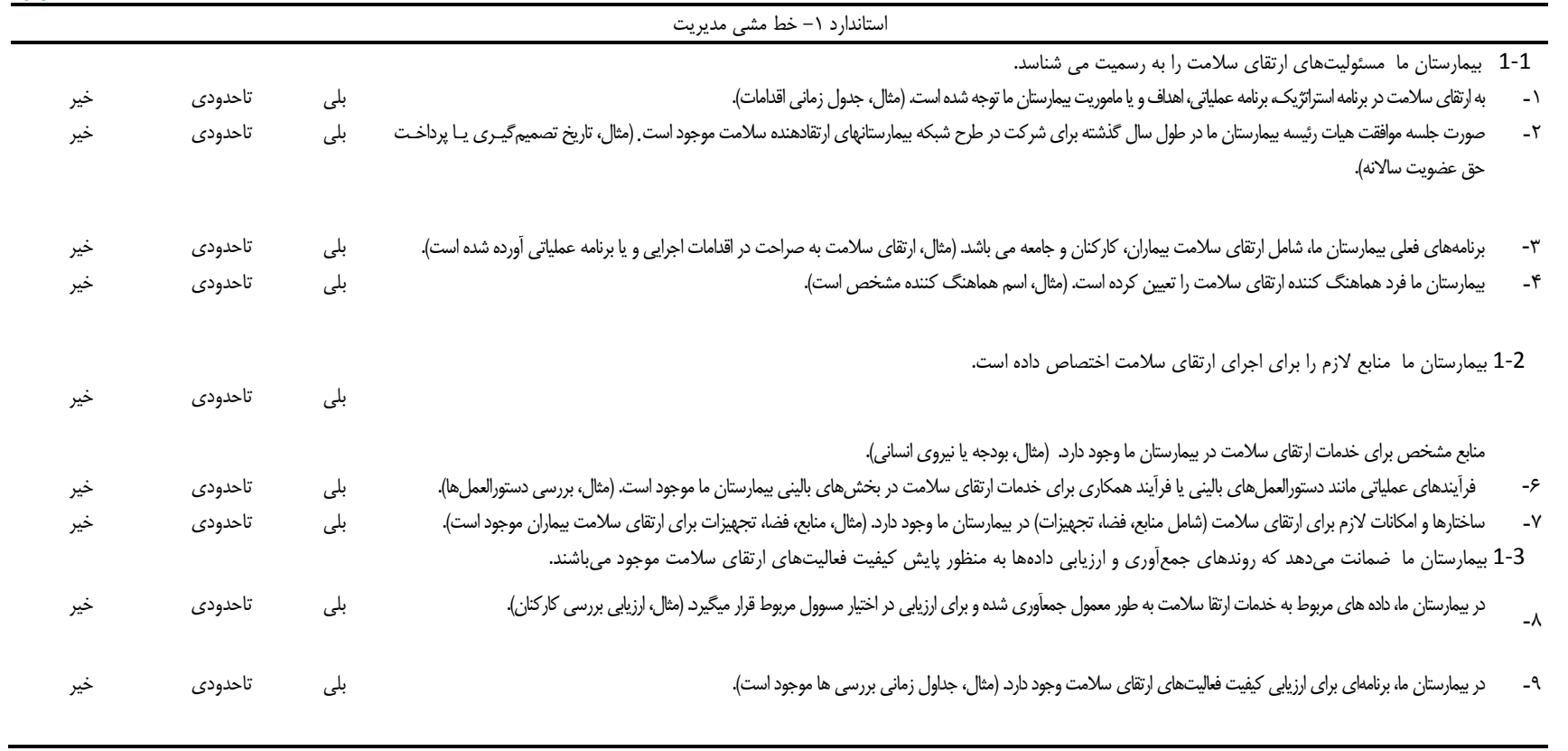

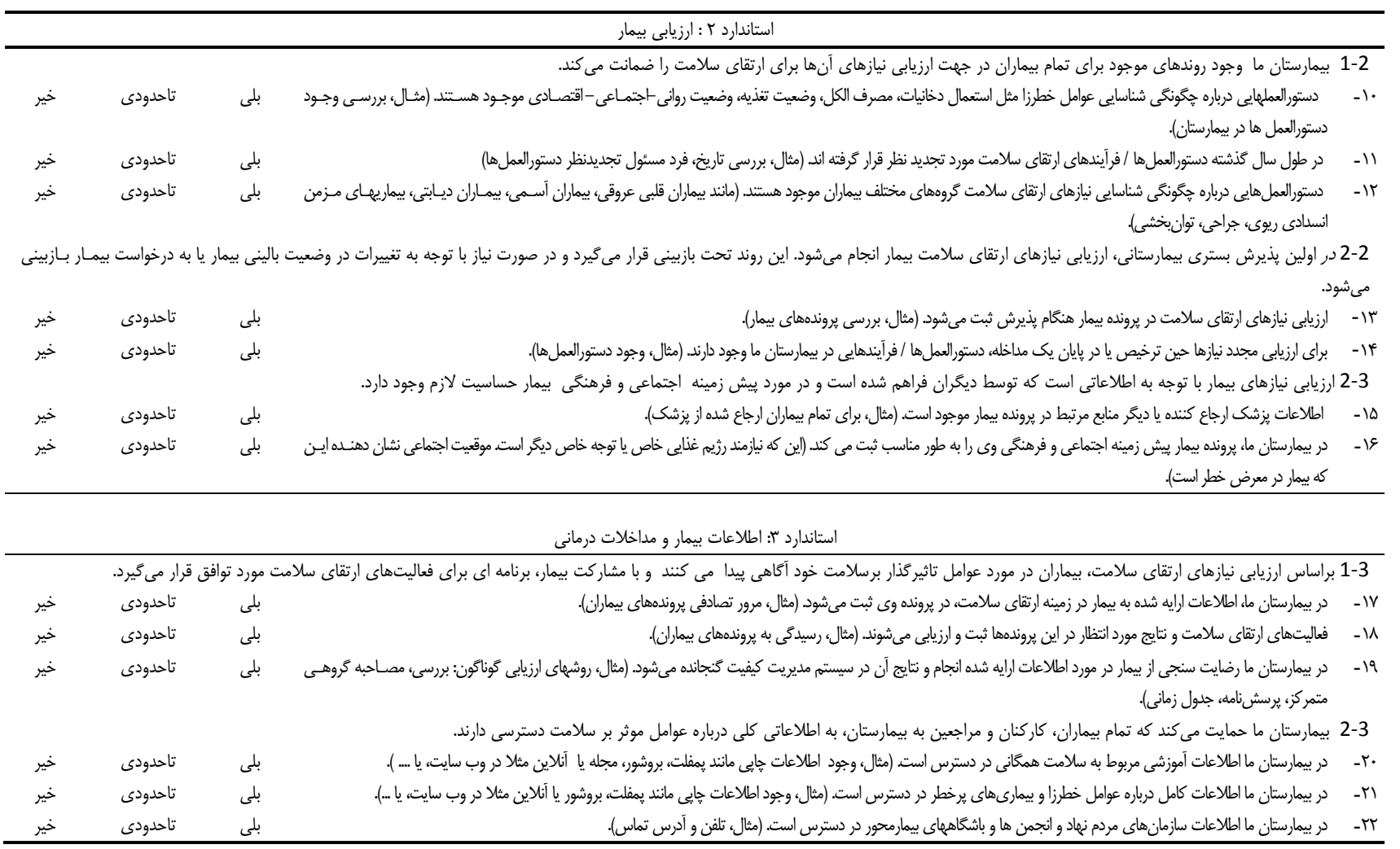


Persian self-assessment form of health promoting hospitals

\begin{tabular}{|c|c|c|c|c|}
\hline \multicolumn{5}{|c|}{ استانداردث: ارتقاى محيط كارى سالم } \\
\hline \multicolumn{5}{|c|}{ 1-4 بيمارستان ما توسعه و اجراى طرح ايجاد يك محيط كارى سالم و ايمن را تضمين مى كند. } \\
\hline خير & تاحدودى & بلى & محيط كارى كاركنان ييمارستان ما، با استانداردها، توصيه ها و شاخصهاى ملى / منطقادى سازكار است. (مثال، قوانين ملى و بين المللى). & $-\pi$ \\
\hline خير & 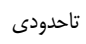 & بلى & كاركنان بيمارستان ما، نيازهاى مربوط به سلامت و ايمنى را رعايت مى كند و تمام خطرات محيط كارى شناسايى شده است. (مثال، دادهاى مربوط به آسيب هاى شغلى را بررسى كنيد). & $-T^{c}$ \\
\hline & & & 2 بيمارستان ما تدوين و اجراى استراتثى جامع منابع انسانى كه شامل آموزش و توسعه مهارتهاى ارتقاى سلامت كاركنان باشد را تضمين مى كند. & $2-4$ \\
\hline خير & 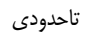 & بلى & كاركنان جديد بيمارستان ما در مورد سياست ارتقاى سلامت، آموزش اوليه بلو ورود را مى ييند. (مثال، مصاحبه با كاركنان جديد) & $-r \Delta$ \\
\hline خير & تاحدودى & بلى & كاركنان تمام بخشهاى بيمارستان ما، از محتواى سياست ارتقاى سلامت بيمارستان ما آكاهى دارند. (مثال، ارزيابى سالانه عملكرد يا شركت كاركنان در برنامه). & E \\
\hline خير & تاحدودى & بلى & يرونده شغلى و ارزيابى عملكرد كاركنان شامل ارتقاى سلامت نيز است. (مثال، مستند شده در يرونده سلامتى كاركنان يا مصاحبه با آنان) & $-T V$ \\
\hline خير & تاحدودى & بلى & فرآيندها و دستورالعمل هاى كارى ارتقاى سلامت در بيمارستان ما، توسط كروههاى جند تخصصى تدوين شداند. (مثال، بررسى فرآيندها، بررسى كاركنان). & $-r \Lambda$ \\
\hline خير & تاحدودى & بلى & 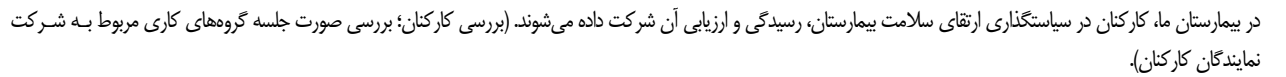 & $-4 q$ \\
\hline خير & 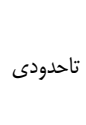 & بلى & 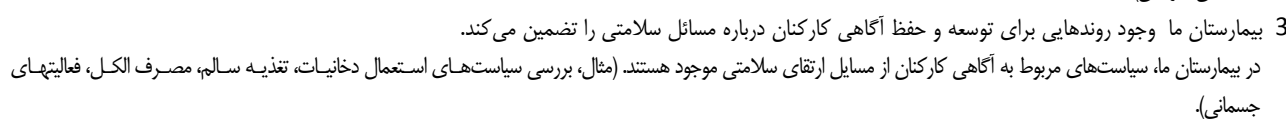 & 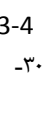 \\
\hline خير & تاحدودى & بلى & در بيمارستان ما، برنامههاى ترك سيكار براى كاركنان سيخارى ارايه مى شود. (مثال، شواهد وجود برنامه ها). & $-\mu$ \\
\hline خير & 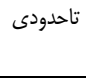 & بلى &  & $-\pi$ \\
\hline \multicolumn{5}{|c|}{ استاندارد ه: استمرار در درمان و همكارى } \\
\hline خير & تاحدودى & بلى & 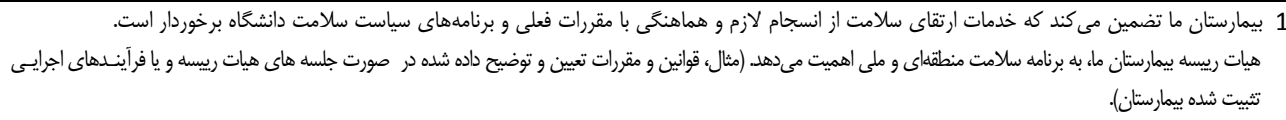 & سוt \\
\hline خير & 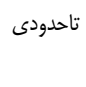 & بلى & شديات رييسه بيمارستان ما، فهرستى از ارايهكتندكان مراقبتهاى سلامتى و اجتماعى كه به صورت مشترى با بيمارستان همكارى مى كند را در اختيار دارد. (مثال، بررسى فهرسـت بـه روز & $-\mu_{c}$ \\
\hline خير & 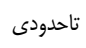 & بلى & همكارى ررون بخشى و يين بخشى ييمارستان ما در حوزه ارتقاى سلامت بر اساس اجراى برنامه سياست سلامت منطقةاىى و ملى است. (مثال، بررسى تناسب). & $-\mu \mathrm{s}$ \\
\hline خير & 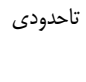 & بلى & 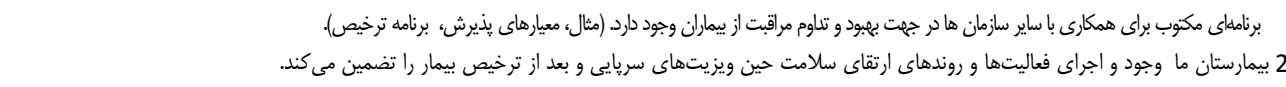 & $2-5$ \\
\hline خير & 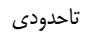 & بلى & به ييمارلن (و خاواده آنها مر صورت لزوم) آمزش هاى بيكيرى قابل فهمر مشاوره سريابى، لرجاعى يا حين ترخيص اده مىشود (مثال، ارزيابى بيماران). & $-4 \mathrm{M}$ \\
\hline خير & 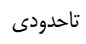 & بلى & فرآيند تبادل اطلاعات درون بخشى و بين بخشى در مورد تمام اطلاعات مرتبط با بيمار وجود دارد. (مثال، بررسى وجود اين فرآيند). & - ג \\
\hline خير & 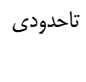 & بلى & از آرجاع دهنده بيمار به بيمارستان ما، به طور منظم خلاصهاى مكتوب از بيمارى فرد و نيازهاى سلامتى بيمار و مداخلات انجام شده توسط بيمارستان را دريافت مى كند (مثال، وجود نسـخهاى & $-{ }^{-19}$ \\
\hline خير & تاحدودى & بلى & درصورت لزوم، برناهه بازتوانى (توانبخشى) كه نقش بيمارستان و سايرين را مشخص كرده است، در برونده بيمار ثبت مى گردد. (مثال، مرور بروندهها). & $-t^{2}$ \\
\hline
\end{tabular}

